\title{
MHC class II transactivator CIITA inhibits Tax-2- mediated HTLV-2 LTR transactivation and viral replication by binding to, and affecting Tax-2 intracellular localization
}

\author{
Chiara Orlandi, Greta Forlani, Giovanna Tosi, Roberto S Accolla* \\ From 15th International Conference on Human Retroviruses: HTLV and Related Viruses \\ Leuven and Gembloux, Belgium. 5-8 June 2011
}

CIITA, the MHC class II transactivator, inhibits the transcriptional function of HTLV-2 (Human T cell Lymphotropic Virus 2) Tax-2 viral transactivator and, consequently, the replication of the virus in human target cells. Here we demonstrate that CIITA and Tax-2 interact in vivo and we identified at least two independent regions, at the 1-252 N-term and at the 410-1130 Cterm, respectively, necessary for this interaction, although only the $\mathrm{N}$-term region mediates Tax-2 functional inhibition. Intracellular localization experiments in 293T cells demonstrate that CIITA and Tax-2, when expressed alone, are present both in the cytoplasm and in the nucleus; when co-expressed, however, Tax-2 mostly co-localize with CIITA in the cytoplasm and around the nuclear membrane. The remaining nuclear Tax-2, also co-localize with CIITA. Interestingly, when CIITA nucleus-cytoplasm shuttling is blocked by leptomycin B treatment, most of the Tax-2 molecules are also blocked and co-localize with CIITA in the nucleus, suggesting that direct CIITA-Tax-2 binding does not preclude Tax-2 entry into the nucleus.

Finally, the nuclear factor NF-YB, a CIITA-binding nuclear protein necessary for the MHC class II gene promoter activation, whose overexpression inhibits Tax2-mediated HTLV-2 LTR transactivation, also strongly binds to Tax-2 in absence of CIITA. Notably, although endogenous NF-YB does not inhibit Tax-2-dependent HTLV-2 LTR transactivation, it still binds to Tax-2, and in presence of CIITA, this binding seems to increase. Taken together these results strongly suggest that that

\footnotetext{
*Correspondence: roberto.accolla@yahoo.it
}

Department of Experimental Medicine, University of Insubria, Varese, 21100, Italy

\section{Biomed Central}

( 2011 Orlandi et al; licensee BioMed Central Ltd. This is an open access article distributed under the terms of the Creative Commons Attribution License (http://creativecommons.org/licenses/by/2.0), which permits unrestricted use, distribution, and reproduction in any medium, provided the original work is properly cited. tivator both directly in the cytoplasm or through a tripartite interaction with NF-YB in the nucleus.

Published: 6 June 2011

doi:10.1186/1742-4690-8-S1-A172

Cite this article as: Orlandi et al: MHC class II transactivator CIITA inhibits Tax-2-mediated HTLV-2 LTR transactivation and viral replication by binding to, and affecting Tax-2 intracellular localization. Retrovirology 2011 8(Suppl 1):A172.

Submit your next manuscript to BioMed Central and take full advantage of:

- Convenient online submission

- Thorough peer review

- No space constraints or color figure charges

- Immediate publication on acceptance

- Inclusion in PubMed, CAS, Scopus and Google Scholar

- Research which is freely available for redistribution Submit your manuscript at
www.biomedcentral.com/submit C Biomed Central
CIITA could inhibit Tax-2 by binding the viral transac- 